\title{
correspondence
}

\section{Letter from Argentina}

SIR,--I welcome the concern Louise Harel, Jose Uriel and Jean-Claude Salomon show to my countrymen ( 3 November, page 8 ) by inviting professionals not to participate in the twelfth International Congress of Cancerology to be held in Buenos Aires, in October 1978.

However, while I believe that sincere international solidarity can be of great help in the fight for universal human rights, and while I welcome the writers' desire to see democracy upheld, I believe their proposal in this case is misguided.

Many countries are suffering from terrorism. In Argentina scientists, professional people, students, workers, policemen and the military, priests, women and children have been affected. It is true that there is a long list of people who have disappeared or been kidnapped and that some have been forced to emigrate by intimidating threats and torture. But action is also being taken against all kinds of terrorism. President Videla has repeatedly declared that the state is the only force charged with the security of people and that any illegal repression will be severely punished. He has also expressed the need for exchange of opinions if Argentina is to be based on a renewed, stable and progressive democracy.

These concepts are shared by the Permanent Assembly for Human Rights and by the Argentine League for the Rights of Man, both functioning legally. Political personalities, cultural and scientific representatives, as well as others from all branches of activities, publicly condemn the terrorist violence and call for an end to persecution and arbitrary repression.

But is a decision to boycott the International Congress an appropriate way of expressing solidarity? Is it in effective way of helping us reach a democratic goal? I think not. One of the objectives of terrorism is to disorganise the life of a country, to create a climate of intimidation and to isolate the nation from the international community. A boycott of the Conference would contribute to this isolation and would favour the plans of terrorists to promote chaos. The fight against terrorism should stem from the organised way of life of the country itself, which will break up antisocial manifestations. The government has assumed this responsibility by proclaiming its monopoly of repressive actions against terrorism. It is also the responsibility of the democratic forces which speak out for the right to work in peace and liberty. This is what scientists, professional people, workers and their institutions and associations are doing. All these activities are proceeding in spite of economic restrictions and social violence and they should be supported.

No matter how great the concern of our colleagues abroad, Argentinians are far more concerned about showing support for security and peace. It is precisely to show solidarity with oui efforts that foreign scientists should come to our country, should acquaint themselves with our complex reality, should make their contributions towards the fight against cancer and should acquaint themselves with the Argentinian work on the subject.

I am making this appeal as a scientist who has been dismissed from his position in the National Council for Scientific and Technical Research (CONICET), for "service reasons", without any justification. I have not emigrated, neither have most of those affected. I have asked for reconsideration and $I$ will continue my fight for justice. I am going to participate in the International Congress of Cancerology with my modest contribution under such difficult circumstances. I am confident that the patriotic forces of our country, both military and civil, will find a way of effectively restoring democracy. All honest Argentinians are striving for this end. The presence of foreign scientists at the Congress will be an expression of respect and solidarity with our human and scientific endeavour when we need it most.

Buenos Aires, Argentina

EMANUEL LEVIN

\section{Go to Argentina}

SIR,-Once more the European scientific community is threatening to boycott the scientists of a specific country because of the type of government they have ("Petition for Argentinian scientists", 3 November, page 8). I think this is unfair to the great majority of scientists and students of the particular country. I would like to comment on this problem by taking the example of Chile, my native country.

As a small country with a low population, mainly supported economically by copper exportation, Chile used to have the reputation of being an example of democracy in a continent where, together with two or three other countries, it was the exception. Its universities had excellent research groups in many disciplines able to compete with scientists from much richer countries.

All this was jeopardised by the 1973 military "putsch"; the research effort was severely affected but not killed (see "Science in Chile since Allende", Nature 265, 486, 1977). Many Chilean scientists left the country, some because of direct persecution, others because of political ideas or moral convictions. The first of these groups was composed of scientists who had key positions during the 1970-73 period, or who were considered to be important by the "new lords". Many of these people were imprisoned and then went abroad through embassies. In the second group are many scientists who had already been abroad and for whom the possibilities of obtaining good positions in the USA and Europe were favourable.

Some university departments had to close down because all the teaching staff had left. This was the case for disciplines like physics and mathematics. In the field of biochemistry, however, an important number stayed, although many left. Who are these women and men who did not leave?

Are they all fascists as is generally assumed, mainly in Europe? One thing is clear to me: the longer they remain isolated from the rest of the world, the more likely it is that they will become convinced by the government of the so-called "general Marxist confabulation against Chile". There may be a small fraction of native academics that is sympathetic to and even enthusiastic about the "junta", but most of the Chilean scientific community is made up of convinced democrats who have supported leftist or left of centre political positions. For professional or familial reasons they have stayed in Chile.

What happens when an invitation or the opportunity to visit Chile is open to a foreign scientist? Immediately thousands of voices full of fury are raised to protest against such support of the authoritarian regime. This is extremely evident among European unions or intellectuals. Of course, other annual exchange programmes organised by certain European governments with other dictatorship-ruled countries do not raise such a reaction. 